\title{
'Believing is adapting': Belief in a just world and emigrants' identification and satisfaction with the host country / 'Creer es adaptarse': Creer en un mundo justo y la identificación y satisfacción de los emigrantes con el país de acogida
}

\author{
Ana C. Leite, Sónia G. Cardoso, André G. Marques \& Catarina Morais
}

To cite this article: Ana C. Leite, Sónia G. Cardoso, André G. Marques \& Catarina Morais (2017) 'Believing is adapting': Belief in a just world and emigrants' identification and satisfaction with the host country / 'Creer es adaptarse': Creer en un mundo justo y la identificación y satisfacción de los emigrantes con el país de acogida, Revista de Psicología Social, 32:2, 424-439, DOI: $\underline{10.1080 / 02134748.2017 .1291743}$

To link to this article: http://dx.doi.org/10.1080/02134748.2017.1291743

Published online: 28 Feb 2017.

Submit your article to this journal $₫$

Llll Article views: 87

Q View related articles ¿

View Crossmark data ¿ 


\title{
'Believing is adapting': Belief in a just world and emigrants' identification and satisfaction with the host country / 'Creer es adaptarse': Creer en un mundo justo y la identificación y satisfacción de los emigrantes con el país de acogida
}

\author{
Ana C. Leite ${ }^{\mathrm{a}}$, Sónia G. Cardoso ${ }^{\mathrm{b}}$, André G. Marques ${ }^{\mathrm{a}}$, and Catarina Morais ${ }^{\mathrm{a}}$ \\ ${ }^{a}$ University of Kent; ${ }^{b}$ Institute of Social Sciences, University of Lisbon \\ (Received 1 February 2016; accepted 12 June 2016)
}

\begin{abstract}
In an era in which Europe is experiencing a new wave of emigration as a result of the economic crisis, it seems socially relevant to study the processes that underlie emigrants' adjustment to their new place of living. Research has thoroughly supported the assumption that believing in a just world is an adaptive mechanism that helps people to deal with uncertainty and harsh realities in life. We propose that the endorsement of such beliefs might also contribute to a positive identification with the host country. Using a sample of Portuguese emigrants $(N=144)$, we demonstrate in a crosssectional design that belief in a just world predicts a positive identification with the host country. In addition, positive levels of identification with the host country predicted higher levels of satisfaction with emigrant life. Theoretical and applied implications are discussed.
\end{abstract}

Keywords: belief in a just world; emigration; migration; identification with the host country; social identity

Resumen: En un periodo en el que Europa experimenta una nueva oleada de emigración a causa de la crisis económica, el estudio de los procesos que subyacen la adaptación de los emigrantes a su nuevo lugar de residencia reviste particular relevancia social. Las investigaciones han apoyado sin reservas la asunción de que creer en un mundo justo es un mecanismo de adaptación que ayuda a las personas a enfrentarse a la incertidumbre y a las duras realidades de la vida. En este artículo sugerimos que la adopción de esta creencia podría contribuir también a una identificación positiva con el país de acogida. Basándonos en una muestra de emigrantes portugueses $(N=144)$, demostramos a través de un diseño transversal que la creencia en un mundo justo predice la identificación positiva con el país de acogida. Además, un

This paper was accepted by the last editorial team. / Este articulo fue aceptado por el anterior equipo editorial.

English version: pp. 424-430 / Versión en español: pp. 431-437

References / Referencias: pp. 437-439

Translated from English / Traducción del inglés: Mercè Rius

Authors' Address / Correspondencia con los autores: Ana C. Leite, Centre for the Study of Group Processes, School of Psychology, University of Kent, Canterbury, CT2 7NP, UK. E-mail: a.leite@kent.ac.uk 
nivel elevado de identificación con el país de acogida predice niveles más elevados de satisfacción con la vida como emigrante. Finalmente se debaten las implicaciones teóricas y prácticas de los resultados obtenidos.

Palabras clave: creencia en un mundo justo; emigración; migración; identificación con el país de acogida; identidad social

The new wave of emigration from Southern Europe targeting other, wealthier, European countries has been exhaustively described in the news (e.g., Ottaviani, 2014, October 2). In fact, the current economic global crisis has shifted the emigration patterns in Europe (International Organization for Migration, 2010). As southern European countries' economies stagnate, citizens are leaving their countries to pursue the new 'European dream' in more favourable economies. For example, about 110,000 Portuguese people left their country in 2013 (Pires, Pereira, Azevedo, \& Ribeiro, 2014). With such high numbers, it is socially relevant to study emigrants' processes of adjustment, especially with the growing support for extremist parties and the opposition to immigration in Europe (Palmer, 2013, November), which often lead to negative attitudes towards immigrants (European Humanist Federation, 2013). Research has established that believing in a just world might have a functional role in helping people to adjust to uncertainty (Furnham, 2003). We suggest that belief in a just world (BJW) might have an adaptive function for emigrants, by enabling the achievement of a positive identification with their host country.

\section{Social identification and emigrants' integration}

Social identity theory (Tajfel \& Turner, 1979) seeks to understand the impact that group memberships have on individuals' self-concept and self-esteem. It assumes that when individuals categorize themselves and others as members of a group, their behaviour is guided by the part of their self-concept associated with their group memberships - that is, their social identity (Abrams \& Hogg, 1988; Tajfel, 1978; Tarrant, North, \& Hargreaves, 2001). Thus, individuals are motivated to obtain a positive value for their social groups and, consequently, for their social identity (Tajfel, 1978). Research supporting the positive consequences that social identity has on individuals is abundant (e.g., Haslam, Jetten, Postmes, \& Haslam, 2009), showing, for example, that social identification predicts well-being (Haslam, O'Brien, Jetten, Vormedal, \& Penna, 2005; Wegge, Van Dick, Fisher, Wecking, \& Moltzen, 2006) and life satisfaction (Haslam et al., 2005).

More important for the present research, social identification also plays a key role in emigrants' integration. Integration, which can be understood as an interactive process between migrants and their host country, has been related to psychological adaptation and low levels of stress (e.g., Heckmann, 2005). Identification with the host country is one of the spheres of migrants' integration (Heckmann, 2005). Indeed, feelings of belongingness to the host country and feelings of being at 'home' can be considered the final step in the integration process, as they capture the sense of being tied to a certain group 
or place (e.g., Black, 2002). In this process, emigrants participate in and are accepted by the new group (Heckmann, 2005; Nesdale \& Mak, 2000). In support of this idea, Nesdale and Mak (2000) showed that identification with the host country is positively affected by the degree to which emigrants feel accepted by the host country.

Identification with the host country can help emigrants to adjust successfully to their new lives in different ways. First of all, belonging to a group provides a sense of security and validates beliefs, opinions and attitudes about social reality, whilst facilitating goal achievement (Festinger, 1950). Second, a strong attachment to the host country is positively associated with educational achievements (Birman, Trickett, \& Vinokuro, 2002; Horenczyk \& Ben-Shalom, 2001), social adaptation and well-being (Phinney, Horenczyk, Liebkind, \& Vedder, 2001). Finally, a positive identification with the host country is associated with a positive self-esteem (Phinney, Cantu, \& Kurtz, 1997), life satisfaction (Angelini, Casi, \& Corazzini, 2014) and positive conditions of life (Nesdale, 2002; Walters, Phythian, \& Anisef, 2007).

These insights suggest that identification with the host country might contribute to emigrants' satisfaction with their new lives. We suggest that a positive social identification with the host country might also play a key role in emigrants' adjustment to their host country. In this sense, a positive social identification with the host country should strongly predict emigrants' satisfaction with their emigrant life.

\section{The role of $B J W$ on identification with the host country}

Other research highlights the importance of individual differences on identification with the host country. According to Bastian and Haslam (2008), essentialist beliefs amongst emigrants moderate the extent to which they identify with their host country. Incidentally, BJW has a functional value in threatening situations (e.g., Correia, Vala, \& Aguiar, 2007) by protecting individuals from negative psychological consequences when they face unjust, harsh realities in life or when they face uncertainty (Correia \& Dalbert, 2007; Furnham, 2003; Lerner, 1980). Moreover, BJW is particularly vital when individuals need to pursue long-term goals since it increases the individuals' belief that they will get what they deserve, while seeing their efforts do not go to waste, but rather as having real purpose (Hafer, 2000). In this sense, we reason that BJW might be an important predictor of the process of integration into the host country.

According to the just world theory (Lerner \& Simmons, 1966), individuals have the basic need of believing that the world is a fair, predictable place, where people get what they deserve. Lerner (1980) argued that such assumptions are a natural and functional motivation that guides individuals towards their goals. In fact, living in unpredictable environments seems to have a negative impact on individuals' wellbeing (Lefcourt, 1976). BJW is understood as a crucial belief that helps individuals to deal with the harsh realities in life, by providing a sense of control over life (Furnham, 2003), and it has been positively associated with self-esteem, well-being (Dalbert, 1999) and life satisfaction (Lipkus, Dalbert, \& Siegler, 1996), and 
negatively correlated with depression (Ritter, Benson, \& Snyder, 1990). In sum, studies consistently support the idea that BJW is functional to individuals since it acts as a coping mechanism (Furnham, 2003) and plays a key role in psychological adjustment (Sutton et al., 2008). In a similar line of reasoning, we further suggest that, due to its general importance on self-esteem and well-being (Dalbert, 1999), BJW might also help migrants cope with the many challenges of emigration. Specifically, we suggest that attachment to the host country (as measured by social identification) might be a consequence of the coping mechanism, which then allows individuals to increase satisfaction with emigration. Therefore, we hypothesize that a stronger BJW increases social identification, which then increases satisfaction with emigration. Research has distinguished between BJW-self and BJW-others (Lipkus et al., 1996; Sutton \& Douglas, 2005), which are associated with different outcomes. Whereas BJW-self is related to positive general well-being, BJW-others is associated with social outcomes (Sutton \& Douglas, 2005). In the present study, we address a research question that relates to individuals' social intergroup context, namely, identification and satisfaction with living in an outgroup country. Even though we are studying individuals' satisfaction with emigration, our goal is to study it from the perspective of social identification (which we found to be the psychological mechanism that links BJW and satisfaction with emigration). Therefore, we considered the use of the BJW-others scale as appropriate, given that it is more applicable for social outcomes (Sutton \& Douglas, 2005).

\section{Overview and hypotheses}

In the present study we investigate the role of BJW on emigrants' identification with the host country and, consequently, on satisfaction with emigration. Specifically, we suggest that BJW might work as a functional mechanism in helping emigrants to adjust to their new culture, by increasing emigrants' identification with their host country. Based on recent developments of the social identification approach (Haslam et al., 2005), we further suggest that the strength of identification with the host country predicts emigrants' satisfaction with emigration. Therefore, we expected higher scores of identification with the host country to be predicted by higher levels of BJW. Furthermore, given the role social identity is known to have on life satisfaction, we expected identification with the host country to predict satisfaction with emigration.

\section{Method}

\section{Participants and procedure}

The sample consisted of 144 Portuguese emigrants (97 female) with ages ranging from 20 to 58 years old $\left(M_{\text {age }}=32.25, S D=9.47\right)$ living in European countries ${ }^{1}$. The majority of participants $(55.1 \%)$ moved to a new country less than six years ago and $85.4 \%$ of the participants were employed at the time. Participants' level of education ranged from primary education (9.2\%), secondary education $(44.3 \%)$ to higher education (46.5\%). All participants were recruited online, via Facebook, and participated voluntarily after reading the informed consent sheet ${ }^{2}$. 


\section{Measures}

\section{Belief in a just world}

BJW was measured with seven items adapted from Sutton and Douglas's (2005) BJW-others scale: 'I believe that people have what they are entitled to', 'I believe that people's commitment is recognized', 'I believe that people deserve the rewards and punishments that they receive', 'I believe that people attract their own misfortunes', 'I believe that people have what they deserve', 'I believe that the rewards and punishments that people receive are fair' and ' $I$ feel that the world is a fair place' ( 1 = 'I strongly disagree'; 7 = 'I strongly agree'). Participants' responses were averaged to a BJW score (Cronbach's alpha $=.85)$.

\section{Identification with the host country}

To assess the extent to which participants identified with their host country, they indicated their agreement with the following items: 'I identify with my host country's citizens' and 'I appreciate the culture and values of the country I live in' ( 1 = 'I strongly disagree'; 7 = 'I strongly agree'). We averaged participants' responses to create an Identification with the Host Country score $(r=.604, p<.001)$.

\section{Satisfaction with emigration}

Participants rated their agreement with the following statements: 'I feel happy living abroad' and 'I feel good living in this country' ( 1 = 'I strongly disagree'; 7 = 'I strongly agree'). We averaged participants' responses to create a Satisfaction with Emigration score $(r=.647, p<.001)$.

\section{Results}

We proposed that a higher endorsement of BJW would predict stronger identification with the host country, which would lead to a higher satisfaction with emigration. We conducted a mediation analysis, using Hayes' (2013) PROCESS macro (Model 4; 5,000 bootstraps) with satisfaction with emigration as the outcome, BJW as the predictor and Identification with the Host Country as the mediator. The means, standard deviations and correlations are presented in Table 1. This model was significant (mediator included), $F(2,141)=65.63, p<.001$, and accounted for $48.21 \%$ of the variance: indirect effect regarding Identification with the Host Country: $b=0.21$, $S E=0.07,95 \% C I[0.08,0.36]$; total effect: $b=0.38, S E=0.10, t=3.90, p<.001$; $95 \% C I[0.19,0.57]$; direct effect: $b=0.17, S E=0.08, t=2.25, p=.026 ; 95 \% C I[0.02$, $0.32]$. In line with our prediction, the effect of BJW on satisfaction with emigration was mediated by identification with the host country (see Figure 1).

\section{Discussion}

In this paper, we extended previous research on identification with the host country by showing that (1) identification with the host country predicts 
Table 1. Correlations between measures, means and standard deviations.

\begin{tabular}{lccc}
\hline & $M(S D)$ & 2 & 3 \\
\hline 1. BJW & $3.73(1.25)$ & $.264^{* *}$ & $.311^{* * *}$ \\
2. Identification with the host country & $4.81(1.42)$ & & $.681^{* * *}$ \\
3. Satisfaction with emigration & $5.32(1.52)$ & & \\
\hline
\end{tabular}

Note: ${ }^{*} p<.05,{ }^{* *} p \leq .005,{ }^{* * *} p \leq .001$.

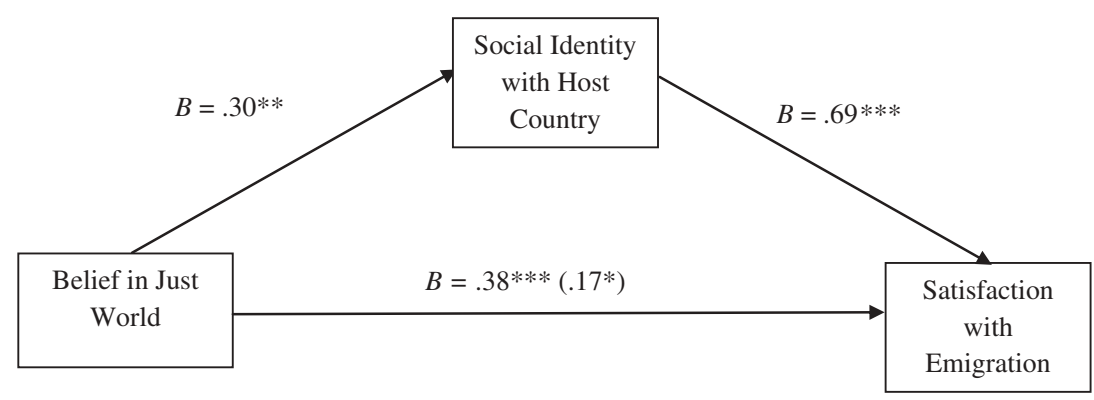

Figure 1. Model testing hypothesis that belief in just world predicts satisfaction with emigration through social identity with host country.

satisfaction with emigration, and (2) BJW plays a key role in predicting emigrants' identification with their host countries. The present results support our reasoning regarding the important role of BJW as an adaptive function for identification with the host country and satisfaction with emigrant life. As Lerner and Miller (1978) stated, 'without such a belief it would be difficult for the individual to commit himself to the pursuit of long range goals or even to the socially regulated behaviour of day to day life' (pp. 1030-31). Indeed, considering that migrating to a different context (with all the changes that comprises culture, values and relationships) implies significant and challenging differences, BJW can provide a crucial adaptive function. Our results suggest that emigrants who endorse just world beliefs more strongly are more positively identified with their host countries. On the contrary, this study provides evidence in support of the assumption that people who believe more strongly that the world acts in a different (unjust) manner may increase the struggle for social adaptation, and thus hinder the individual's identification with the host country.

Additionally, satisfaction with emigration is also influenced positively by their positive social identification. This result is consistent with previous research that has been highlighting the important role of social identification as a predictor of well-being and life satisfaction (Haslam et al., 2005; Wegge et al., 2006).

The present research might have important implications for countries' migration policy-making. Taking into account emigrants' relationship with the host country may help to solve some of the issues highlighted by the Council of Europe (2012), namely the ones related to society fragmentation, which are still 
one of the major obstacles to emigrants' integration in the host country. Our study shows the importance of social identification as the psychological mechanism that links (to some extent) BJW and satisfaction with emigration. Similarly, others have shown that social identification is associated with general life satisfaction (Haslam et al., 2005). This leads us to believe that interventions that focus on improving emigrants' identification with the host country could be beneficial in the process of integration and in improving satisfaction with emigration.

It is important to note that this study employed a correlational design, and therefore causality cannot be established. In this paper, we demonstrate that stronger BJW predicts stronger satisfaction with emigration, a process partially mediated by identification with the host country. However, due to the crosssectional nature of the study, it is also plausible that the more satisfied migrants are with their lives, the more identified they become with their host countries, for example. Here, we established the direction of this path on previous research that has successfully demonstrated the relation between social identification and life satisfaction (e.g., Haslam et al., 2005). Similarly, drawing on BJW literature, we propose that BJW might be a powerful mechanism through which migrants' integration is facilitated and, thus, we hypothesized the order here presented. However, to the best of our knowledge, this is the first study that relates both concepts, and future research using experimental and longitudinal data is necessary to provide further support for these findings. Additionally, in this study we focus on a specific sample and, therefore, our results do not allow us presently to discuss the applicability of our model to different cultural contexts. Future research should investigate whether the pattern of results applies to other samples. Another potential limitation refers to the scales used to measure identification with the host country and satisfaction with emigration. These scales were strongly correlated in this study and, therefore, future research should use stronger measures in order to effectively empirically separate the two constructs.

To conclude, this study offers preliminary evidence on the relation between emigrants' just world beliefs and their identification with their host country and, consequently, satisfaction with emigration. Results suggest that satisfaction with emigration is not a simple process; rather it seems to occur in the interplay of individual beliefs and identification with the host country. In fact, we observed that believing in a just world might have important consequences on the psychological process of identification with the host country and also play a key role in satisfaction with emigration.

\section{Notes}

1. France $(n=53)$, Switzerland $(n=24)$, UK $(n=22)$, Germany $(n=16)$, Austria $(n=$ $7)$, Belgium $(n=7)$, Ireland $(n=5)$, Luxembourg $(n=5)$, Spain $(n=2)$, Norway $(n=$ $1)$, Sweden $(n=1)$, undefined $(n=1)$.

2. This study was part of a larger-scale investigation including measures that form part of a separate project. 


\section{'Creer es adaptarse': Creer en un mundo justo y la identificación y satisfacción de los emigrantes con el país de acogida}

A través de las noticias nos llegan descripciones detalladas de las nuevas oleadas de emigración que se dirigen hacia el sur de Europa, con la intención de alcanzar otros países europeos más prósperos (e. g., Ottaviani, 2014, Octubre 2). De hecho, la actual crisis económica ha modificado los patrones migratorios en Europa (Organización Internacional para las Migraciones, 2010). Con el estancamiento de las economías de los países del sur de Europa, sus ciudadanos abandonan estos países en busca del nuevo 'sueño europeo' en economías más boyantes. Por ejemplo, en 2013, aproximadamente 110,000 portugueses abandonaron su país (Pires, Pereira, Azevedo, \& Ribeiro, 2014). Frente a cifras de esta envergadura, el estudio de los procesos de ajuste de los emigrantes se antoja socialmente relevante, especialmente ante el creciente apoyo de la sociedad a los partidos más extremistas y la visible oposición a la emigración en Europa (Palmer, 2013, Noviembre), que, con frecuencia, desemboca en actitudes negativas frente a los inmigrantes (Federación Humanista Europea, 2013). Investigaciones previas han establecido que la creencia en un mundo justo podría desempeñar un rol funcional y ayudar a los individuos a adaptarse a la incertidumbre (Furnham, 2003). En este artículo planteamos que la creencia en un mundo justo (CMJ) podría ejercer una función de adaptación para el emigrante, facilitando su identificación positiva con el país de acogida.

\section{Identificación social e integración de los emigrantes}

La teoría de la identidad social (Tajfel \& Turner, 1979) trata de entender el impacto que la pertenencia a un grupo puede tener en el autoconcepto y la autoestima del individuo. Se asume que, cuando las personas se categorizan a sí mismas y a los demás como miembros de un grupo, su comportamiento está guiado por aquella parte de su autoconcepto que está asociada con su pertenencia al grupo; es decir, su identidad social (Abrams \& Hogg, 1988; Tajfel, 1978; Tarrant, North, \& Hargreaves, 2001). Así, las personas se sienten motivadas por alcanzar un valor positivo para sus grupos sociales y, por consiguiente, para su identidad social (Tajfel, 1978). Existen numerosas investigaciones que corroboran las consecuencias positivas de la identidad social en el individuo (e.g., Haslam, Jetten, Postmes, \& Haslam, 2009) y revelan, por ejemplo, que la identificación social predice el bienestar (Haslam, O’Brien, Jetten, Vormedal, \& Penna, 2005; Wegge, Van Dick, Fisher, Wecking, \& Moltzen, 2006) y la satisfacción con la vida (Haslam et al., 2005). 
Más importante aún para nuestra investigación, la identificación social desempeña también una función clave en la integración del emigrante. La integración, que puede entenderse como un proceso interactivo entre los emigrantes y su país de acogida, se ha relacionado con la adaptación psicológica y con niveles reducidos de estrés (e.g., Heckmann, 2005). La identificación con el país de acogida es una de las esferas de la integración de los migrantes (Heckmann, 2005). De hecho, los sentimientos de pertenencia al país de acogida y de sentirse 'en casa' podrían considerarse el último paso en el proceso de integración, puesto que capturan el sentimiento de sentirse ligado a un grupo o lugar determinado (e.g., Black, 2002). Durante este proceso, los emigrantes pasan a formar parte de un nuevo grupo y son aceptados por este (Heckmann, 2005; Nesdale \& Mak, 2000). Para corroborar esta idea, Nesdale y Mak (2000) mostraron que la identificación con el país de acogida recibe una influencia positiva del grado en que los emigrantes se sienten aceptados por este.

La identificación con el país de acogida puede ayudar al emigrante a adaptarse con éxito a su nueva vida de diversas maneras. En primer lugar, la pertenencia a un grupo produce un sentimiento de seguridad; valida las creencias, las opiniones y las actitudes sobre la realidad social, al tiempo que facilita la consecución de metas (Festinger, 1950). En segundo lugar, un vínculo fuerte con el país de acogida se asocia positivamente con el rendimiento académico (Birman, Trickett, \& Vinokuro, 2002; Horenczyk \& Ben-Shalom, 2001), la adaptación social y el bienestar (Phinney, Horenczyk, Liebkind, \& Vedder, 2001). Por último, la identificación positiva con el país de acogida se ha asociado con una autoestima positiva (Phinney, Cantu, \& Kurtz, 1997), satisfacción personal (Angelini, Casi, \& Corazzini, 2014), y condiciones vitales positivas (Nesdale, 2002; Walters, Phythian, \& Anisef, 2007).

Estos hallazgos sugieren que la identificación con el país de acogida podría contribuir a la satisfacción de los emigrantes con sus nuevas vidas. En este artículo proponemos que la identificación social positiva con el país de acogida también podría ejercer una función clave en el ajuste de los emigrantes al país de adopción. En este sentido, la identificación social positiva con el país de acogida debería predecir de manera clara la satisfacción de los emigrantes con su nueva vida como tal.

\section{El papel de la CMJ en la identificación con el país de acogida}

Otras investigaciones ponen de relieve la importancia de las diferencias individuales en la identificación con el país de acogida. Según Bastian y Haslam (2008), las creencias esencialistas entre los emigrantes moderan el grado en que estos se identifican con sus respectivos países de acogida. Por cierto, la CMJ tiene un valor funcional en situaciones de amenaza (e.g., Correia, Vala, \& Aguiar, 2007) en tanto que protege al individuo de ciertas consecuencias psicológicas negativas cuando se enfrenta a realidades duras e injustas de la vida real o a una incertidumbre (Correia \& Dalbert, 2007; Furnham, 2003; Lerner, 1980). Del mismo modo, la CMJ es particularmente clave cuando las personas necesitan alcanzar metas a largo plazo, 
puesto que contribuye a reforzar la convicción del individuo de que conseguirá aquello que merece, por lo que sus esfuerzos no son en vano, sino que tienen un objetivo real (Hafer, 2000). En este sentido, argumentamos que la CMJ podría ser un predictor importante del proceso de integración en el país de acogida.

Según la teoría del mundo justo (Lerner \& Simmons, 1966), las personas tienen la necesidad básica de creer que el mundo es un lugar justo y predecible, en el que todos obtienen lo que merecen. Learner (1980) defendía que estas creencias constituían una motivación funcional natural que guía al individuo hacia sus metas. De hecho, habitar un entorno impredecible parece tener un impacto negativo en el bienestar de la persona (Lefcourt, 1976). La CMJ se considera una creencia esencial que ayuda al individuo a enfrentarse a las duras realidades de la vida, favoreciendo un sentimiento de control sobre la misma (Furnham, 2003), y se ha relacionado positivamente con la autoestima, el bienestar (Dalbert, 1999) y la satisfacción con la vida (Lipkus, Dalbert, \& Siegler, 1996), mientras que muestra una correlación negativa con la depresión (Ritter, Benson, \& Snyder, 1990). En resumen, múltiples estudios corroboran consistentemente la idea de que la $\mathrm{CMJ}$ tiene una aplicación funcional para el individuo, puesto que actúa a modo de mecanismo de adaptación (Furnham, 2003) y ejerce una función esencial en su adaptación psicológica (Sutton et al., 2008). En esta misma línea de pensamiento, sugerimos además que, debido a su importancia global en la autoestima y el bienestar del individuo (Dalbert, 1999), la CMJ también podría ayudar a los emigrantes a afrontar los múltiples retos de la emigración. En particular, sugerimos que la afiliación al país de acogida (medida a través de la identificación social) podría ser una consecuencia de un mecanismo de adaptación que, a su vez, permite a las personas sentirse más satisfechos con la emigración. Por tanto, planteamos la hipótesis de que una CMJ más fuerte aumenta la identificación social, y que esta, a su vez, aumenta la satisfacción con la emigración. Investigaciones previas distinguen entre la CMJ-propia y la CMJ-otros ( $B J W$ self y BJW-others, en inglés; Lipkus et al., 1996; Sutton \& Douglas, 2005), que se asocian a diferentes resultados. Mientras que la CMJ-propia está relacionada con un bienestar general positivo, la CMJ-otros se asocia con resultados sociales (Sutton \& Douglas, 2005). En este estudio, planteamos una pregunta de investigación enfocada en el contexto social intergrupal del individuo, es decir, en su identificación y satisfacción sobre su existencia en el país de un exogrupo. A pesar de estudiar la satisfacción personal con la emigración, nuestro objetivo es estudiarla desde el punto de vista de la identificación social (dado que este es el mecanismo psicológico que relaciona la CMJ y la satisfacción con la emigración). Por tanto, hemos considerado apropiado el uso de la escala CMJ-otros, dada su mayor aplicabilidad para resultados sociales (Sutton \& Douglas, 2005).

\section{Síntesis e hipótesis}

En este estudio investigamos el papel de la CMJ en la identificación de los emigrantes con el país de acogida $\mathrm{y}$, por tanto, en su satisfacción con la emigración. En particular, sugerimos que la CMJ podría ejercer de mecanismo 
funcional que ayudaría a los emigrantes a adaptarse a la nueva cultura, incrementando su identificación con el país de acogida. Basándonos en avances recientes del enfoque de identificación social (Haslam et al., 2005), sugerimos también que el nivel de identificación con el país de acogida predice la satisfacción del emigrante con la emigración. Por tanto, esperamos que niveles más elevados de CMJ sean predictores de niveles más elevados de identificación con el país de acogida. Además, dado el conocido papel que la identidad social desempeña en la satisfacción con la vida, esperamos que la identificación con el país de acogida predecirá la satisfacción con la emigración.

\section{Método}

\section{Participantes y procedimiento}

La muestra estaba formada por 144 emigrantes portugueses (97 mujeres) de entre 20 y 58 años $\left(M_{\text {edad }}=32.25, D T=9.47\right)$ y residentes en países europeos ${ }^{1}$. La mayoría de ellos (55.1\%) se habían trasladado a otro país en los últimos seis años y un $85.4 \%$ de los participantes estaban trabajando en ese momento. El nivel educativo de los participantes variaba entre Primaria (9.2\%), Secundaria (44.3\%) y Universitaria (46.5\%). Todos los participantes fueron reclutados en línea, a través de Facebook, y participaron voluntariamente tras haber leído el documento de consentimiento informado ${ }^{2}$.

\section{Medidas}

Creencia en un mundo justo

La CMJ se midió a través de siete ítems adaptados de la escala de Sutton y Douglas (2005) 'CMJ-otros': 'Creo que las personas obtienen lo que se merecen', 'Creo que el esfuerzo de las personas es reconocido', 'Creo que las personas merecen las recompensas y los castigos que reciben', 'Creo que las personas atraen sus propias desgracias', 'Creo que las recompensas y los castigos que la gente recibe son justos' y 'Creo que el mundo es un lugar justo' $(1=$ 'totalmente en desacuerdo'; 7 = 'totalmente de acuerdo'). Con las respuestas de los participantes se obtuvo un valor medio de CMJ (alfa de Cronbach $=.85$ ).

\section{Identificación con el país de acogida}

Para evaluar el grado en que los participantes se identificaban con su país de acogida, estos indicaban su nivel de acuerdo con los siguientes ítems: "Me identifico con los ciudadanos de mi país de acogida' y 'Aprecio la cultura y los valores del país en el que resido' $(1=$ 'totalmente en desacuerdo'; 7 = 'totalmente de acuerdo'). Para crear un valor de identificación con el país de acogida, se obtuvo la media de las respuestas de los participantes $(r=.604, p<.001)$. 


\section{Satisfacción con la emigración}

Los participantes evaluaron su nivel de acuerdo con los siguientes enunciados: 'Me siento feliz viviendo en el extranjero' y 'Me siento bien viviendo en este país' $(1=$ 'totalmente en desacuerdo'; 7 = 'totalmente de acuerdo'). Con la media de las respuestas de los participantes, se obtuvo un valor de satisfacción con la emigración $(r=.647, p<.001)$.

\section{Resultados}

Proponíamos que un nivel más elevado de CMJ predeciría niveles más altos de identificación con el país de acogida, lo que, a su vez, resultaría en un mayor nivel de satisfacción con la emigración. Realizamos un análisis de mediación utilizando la macro PROCESS de Hayes (2013; modelo 4, 5,000 iteraciones) con la satisfacción con la emigración como resultado, la CMJ como predictor y la identificación con el país de acogida como mediador. Las medias, desviaciones típicas y correlaciones se presentan en la Tabla 1. Este modelo era significativo (incluido el mediador), $F(2,141)=65.63, p<.001$, y explicaba el $48.21 \%$ de la varianza; efecto indirecto en relación con la identificación con el país de acogida: $b=0.21, S E=0.07,95 \% C I[0.08,0.36]$; efecto total: $b=0.38, S E=0.10$, $t=3.90, p<.001 ; 95 \% C I[0.19,0.57]$; efecto directo: $b=0.17, S E=0.08$, $t=2.25, p=.026 ; 95 \% C I[0.02,0.32]$. En línea con nuestra predicción, el efecto de la CMJ sobre la satisfacción con la emigración estaba mediado por la identificación con el país de acogida (Figura 1).

\section{Discusión}

En este artículo hemos ampliado investigaciones anteriores sobre la identificación con el país de acogida, demostrando que (1) la identificación con el país de acogida predice la satisfacción con la emigración, y (2) la CMJ ejerce un papel clave en la predicción de la identificación del emigrante con su país de acogida. Los resultados obtenidos corroboran nuestro razonamiento sobre la importancia del papel de la CMJ como función adaptativa para la identificación con el país de acogida y la satisfacción con la vida de emigrante. Como afirmaron Lerner y Miller (1978), 'sin esta creencia, sería difícil para el individuo comprometerse con la consecución de metas a largo plazo o incluso con el comportamiento cotidiano, regulado socialmente' (pp. 1030-31, traducción propia). Ciertamente, teniendo en cuenta que emigrar a un contexto diferente (con todos los cambios que eso conlleva; cultura,

Tabla 1. Correlaciones entre medidas, medias y desviación típica (DT).

\begin{tabular}{lccc}
\hline & $M(D T)$ & 2 & 3 \\
\hline 1. CMJ & $3.73(1.25)$ & $.264^{* *}$ & $.311^{* * *}$ \\
2. Identificación con el país de acogida & $4.81(1.42)$ & & $.681^{* * *}$ \\
3. Satisfacción con la emigración & $5.32(1.52)$ & & \\
\hline
\end{tabular}

Nota: ${ }^{*} p<.05, * * p \leq .005,{ }^{* * *} p \leq .001$. 


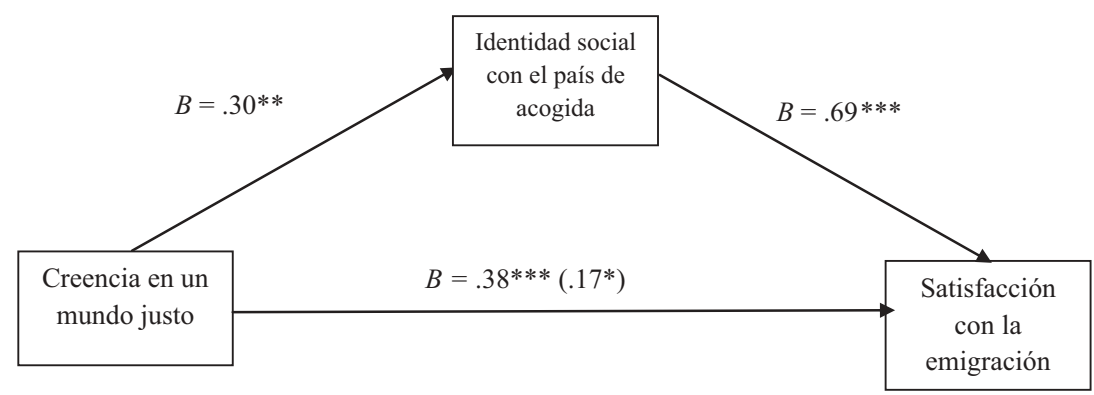

Figura 1. Modelo de comprobación de la hipótesis que plantea que la creencia en un mundo justo $(\mathrm{CMJ})$ predice la satisfacción con la emigración a través de la identidad social con el país de acogida.

valores y relaciones) implica diferencias significativas que pueden suponer un reto, la CMJ puede suponer una función adaptativa clave. Nuestros resultados sugieren que los emigrantes que se adhieren con mayor vehemencia a la creencia en un mundo justo se identifican más intensamente con sus países de acogida. Por el contrario, este estudio ofrece evidencia en apoyo de la asunción de que las personas que creen con mayor convicción que el mundo actúa de manera diferente (injusta) podrían tener mayores dificultades en la adaptación social y, por tanto, su identificación con el país de acogida se vería afectada.

Asimismo, la satisfacción con la emigración también está influida positivamente por la identificación social positiva. Este resultado está en línea con los de investigaciones previas que ponían de relieve la importancia del papel de la identificación social como predictor del bienestar y de la satisfacción con la vida (Haslam et al., 2005; Wegge et al., 2006).

Este trabajo de investigación podría tener importantes implicaciones para las políticas migratorias de los distintos países, teniendo en cuenta que la relación de los emigrantes con el país de acogida podría ayudar a resolver algunas de las cuestiones señaladas por el Consejo de Europa (2012), relacionadas con la fragmentación de la sociedad, que todavía constituyen uno de los mayores obstáculos a la integración de los emigrantes en el país de acogida. Nuestro estudio demuestra la importancia de la identificación social como el mecanismo psicológico que vincula (hasta cierto punto) la CMJ y la satisfacción con la emigración. Del mismo modo, otros estudios han demostrado que la identificación social está asociada con la satisfacción con la vida en general (Haslam et al., 2005). Ello nos lleva a creer que las intervenciones centradas en mejorar la identificación de los emigrantes con el país de acogida podrían ser de ayuda en el proceso de integración y en mejorar la satisfacción con la emigración.

Es importante señalar que en este estudio se utilizó un diseño correlacional y, por tanto, no se pudo determinar la causalidad. En el artículo demostramos que una CMJ más fuerte predice mayor nivel de satisfacción con la emigración, un proceso mediado por la identificación con el país de acogida. No obstante, debido a la naturaleza transversal del estudio, también es plausible que cuanto más satisfechos estén los emigrantes con sus vidas, tanto más se identifiquen con sus respectivos 
países de acogida, por ejemplo. Aquí, establecimos la dirección de esta relación basándonos en investigaciones anteriores que han logrado demostrar la relación entre identificación social y satisfacción con la vida (e.g., Haslam et al., 2005). Del mismo modo, basándonos en la bibliografía sobre la $\mathrm{CMJ}$, proponemos que esta creencia podría ser un potente mecanismo para facilitar la integración de los inmigrantes $\mathrm{y}$, por tanto, planteamos la hipótesis con el orden que presentamos. No obstante, por lo que sabemos, este es el primer estudio que relaciona ambos conceptos, y será necesario realizar investigaciones adicionales utilizando datos experimentales y longitudinales para corroborar nuestros resultados. Asimismo, en este estudio nos centramos en una muestra específica por lo que nuestros resultados no nos permiten debatir en este momento la aplicabilidad de nuestro modelo a otros contextos culturales distintos. Futuras investigaciones deberán estudiar si nuestro patrón de resultados es aplicable a otras muestras. Otra posible limitación del estudio se refiere a las escalas utilizadas para medir la identificación con el país de acogida y la satisfacción con la emigración. Estas escalas presentan una fuerte correlación en este estudio y, por tanto, futuras investigaciones deberían hacer uso de otras medidas más sólidas para separar empíricamente ambos constructos.

En conclusión, este estudio ofrece evidencias preliminares de la relación entre la creencia de los emigrantes en un mundo justo y su identificación con el país de acogida, $\mathrm{y}$, por tanto, su satisfacción con la emigración. Los resultados sugieren que la satisfacción con la emigración no es un proceso sencillo, sino que parece tener lugar con la interacción entre las creencias del individuo y su identificación con el país de acogida. De hecho, hemos observado que la creencia en un mundo justo podría tener consecuencias importantes en el proceso psicológico de identificación con el país de acogida y desempeñar un papel clave en la satisfacción con la emigración.

\section{Notas}

1. Francia $(n=53)$, Suiza $(n=24)$, Reino Unido $(n=22)$, Alemania $(n=16)$, Austria $(n$ $=7)$, Bélgica $(n=7)$, Irlanda $(n=5)$, Luxemburgo $(n=5)$, España $(n=2)$, Noruega $(n=1)$, Suecia $(n=1)$, sin definir $(n=1)$.

2. Este estudio forma parte de una investigación de mayor escala que incluye medidas que forman parte de un proyecto diferente.

\section{Disclosure statement}

No potential conflict of interest was reported by the authors. / Los autores no han referido ningún potencial conflicto de interés en relación con este artículo.

\section{References / Referencias}

Abrams, D., \& Hogg, M. (1988). Comments on the motivational status of self-esteem in social identity and intergroup discrimination. European Journal of Social Psychology, 18, 317-334. doi:10.1002/ejsp.2420180403

Angelini, V., Casi, L., \& Corazzini, L. (2014). Life satisfaction of immigrants: Does cultural assimilation matter? Retrieved from the SOEPpapers http://www.diw.de/ soeppapersSSRNElectronic Journal 10.2139/ssrn.2439643 
Bastian, B., \& Haslam, N. (2008). Immigration from the perspective of hosts and immigrants: Roles of psychological essentialism and social identity. Asian Journal of Social Psychology, 11, 127-140. doi:10.1111/j.1467-839X.2008.00250.x

Birman, D., Trickett, E. J., \& Vinokurov, A. (2002). Acculturation and adaptation of Soviet Jewish refugee adolescents: Predictors of adjustment across life domains. American Journal of Community Psychology, 30, 585-607. doi:10.1023/A:1016323213871

Black, R. (2002). Conceptions of 'home' and the political geography of refugee repatriation: Between assumption and contested reality in Bosnia-Herzegovina. Applied Geography, 22, 123-138. doi:10.1016/S0143-6228(02)00003-6

Correia, I., \& Dalbert, C. (2007). Belief in a just world, justice concerns, and well-being at Portuguese schools. European Journal of Psychology of Education, 22, 421-437. doi:10.1007/BF03173464

Correia, I., Vala, J., \& Aguiar, P. (2007). Victim's innocence, social categorization and the threat to the belief in a just world. Journal of Experimental Social Psychology, 43, 3138. doi:10.1016/j.jesp.2005.12.010

Council of Europe. (2012). Building migrants' belonging through positive interactions: A guide for policy-makers and practitioners. Retrieved from: http://www.coe.int/t/democ racy/migration/Source/migration/EnglishMigrantBelongingWeb.pdf

Dalbert, C. (1999). The world is more just for me than generally: About the personal belief in a just world scale's validity. Social Justice Research, 12, 79-98. doi:10.1023/ A:1022091609047

European Humanist Federation. (2013). The European Union and the challenge of extremism and populism: How to protect democracy and the rule of law in Europe? Retrieved from http://ec.europa.eu/justice/events/assises-justice-2013/files/contribu tions/24.europeanhumanistfederationtheeuandthechallengeofextremismandpopulism_ ehf_en.pdf

Festinger, L. (1950). Informal social communication. Psychological Review, 57, 271-282. doi: $10.1037 / \mathrm{h} 0056932$

Furnham, A. (2003). Belief in a just world: Research progress over the past decade. Personality and Individual Differences, 34, 795-817. doi:10.1016/S0191-8869(02) 00072-7

Hafer, C. L. (2000). Investment in long-term goals and commitment to just means drive the need to believe in a just world. Personality and Social Psychology Bulletin, 26, 1059-1073. doi:10.1177/01461672002611004

Haslam, S. A., Jetten, J., Postmes, T., \& Haslam, C. (2009). Social identity, health and well-being: An emerging agenda for applied psychology. Applied Psychology, 58, 123. doi:10.1111/j.1464-0597.2008.00379.x

Haslam, S. A., O’Brien, A., Jetten, J., Vormedal, K., \& Penna, S. (2005). Taking the strain: Social identity, social support, and the experience of stress. British Journal of Social Psychology, 44, 355-370. doi:10.1348/014466605X37468

Hayes, A. F. (2013). Introduction to mediation, moderation, and conditional process analysis. New York, NY: The Guildford Press.

Heckmann, F. (2005). Integration and Integration Policies. Bamberg: European Forum for Migration Studies.

Horenczyk, G., \& Ben-Shalom, U. (2001). Multicultural identities and adaptation of young immigrants in Israel. In N. Ken Shimahara, I. Z. Holowinsky, \& S. Tomlinson-Clarke (Eds.), Ethnicity, race, and nationality in education: A global perspective (pp. 55-78). Mahwah, NJ: Lawrence Erlbaum Associates, Inc.

International Organization for Migration. (2010). Migration and the economic crisis in the European Union: Implications for policy. Retrieved from http://publications.iom.int/ bookstore/free/Migration and the Economic Crisis.pdf

Lefcourt, H. M. (1976). Locus of control. New York, NY: Lawrence Erlbaum Associates. 
Lerner, M. J. (1980). The belief in a just world: A fundamental delusion. New York, NY: Plenum Press.

Lerner, M. J., \& Miller, D. T. (1978). Just world research and the attribution process: Looking back and ahead. Psychological Bulletin, 85, 1030-1051. doi:10.1037/00332909.85.5.1030

Lerner, M. J., \& Simmons, C. H. (1966). Observer's reaction to the "innocent victim": Compassion or rejection? Journal of Personality and Social Psychology, 4, 203-210. doi: $10.1037 / \mathrm{h} 0023562$

Lipkus, I. M., Dalbert, C., \& Siegler, I. C. (1996). The importance of distinguishing the belief in a just world for self versus for others: Implications for psychological wellbeing. Personality and Social Psychology Bulletin, 22, 666-677. doi:10.1177/ 0146167296227002

Nesdale, D. (2002). Acculturation attitudes and the ethnic and host-country identification of immigrants. Journal of Applied Social Psychology, 32, 1488-1507. doi:10.1111/ j.1559-1816.2002.tb01448.x

Nesdale, D., \& Mak, A. S. (2000). Immigrant acculturation attitudes and host country identification. Journal of Community \& Applied Social Psychology, 10, 483-495. doi:10.1002/1099-1298(200011/12)10:6<483::AID-CASP580>3.0.CO;2-0

Ottaviani, J. (2014, October 2). Crowdsourcing youth migration from southern Europe to the UK. The Guardian. Retrieved from http://www.theguardian.com

Palmer, J. (2013, November 15). The rise of far right parties across Europe is a chilling echo of the 1930s. The Guardian. Retrieved from http://www.theguardian.com

Phinney, J. S., Cantu, C. L., \& Kurtz, D. A. (1997). Ethnic and American identity as predictors of self-esteem among African American, Latino, and White adolescents. Journal of Youth and Adolescence, 26, 165-185. doi:10.1023/A:1024500514834

Phinney, J. S., Horenczyk, G., Liebkind, K., \& Vedder, P. (2001). Ethnic identity, immigration, and well-being: An interactional perspective. Journal of Social Issues, 57, 493-510. doi:10.1111/0022-4537.00225

Pires, R. P., Pereira, C., Azevedo, J., \& Ribeiro, A. C. (2014). Emigração Portuguesa: Relatório Estatístico 2014. Retrieved from http://www.observatorioemigracao.pt/

Ritter, C., Benson, D. E., \& Snyder, C. (1990). Belief in a just world and depression. Sociological Perspectives, 33, 235-252. doi:10.2307/1389045

Sutton, R. M., \& Douglas, K. M. (2005). Justice for all, or just for me? More evidence of the importance of the self-other distinction in just-world beliefs. Personality and Individual Differences, 39, 637-645. doi:10.1016/j.paid.2005.02.010

Sutton, R. M., Douglas, K. M., Wilkin, K., Elder, T., Cole, J., \& Stathi, S. (2008). Justice for whom, exactly? Beliefs in justice for the self and various others. Personality and Social Psychology Bulletin, 34, 528-541. doi:10.1177/0146167207312526

Tajfel, H. (1978). Differentiation between social groups: Studies in the social psychology of intergroup relations. London: Academic Press.

Tajfel, H., \& Turner, J. C. (1979). An integrative theory of intergroup conflict. In W. G. Austin \& S. Worchel (Eds.), The social psychology of intergroup relations (pp. 3347). Monterey, CA: Brooks-Cole.

Tarrant, M., North, A. C., \& Hargreaves, D. J. (2001). Social categorization, self-esteem, and the estimated musical preferences of male adolescents. The Journal of Social Psychology, 141, 565-581. doi:10.1080/00224540109600572

Walters, D., Phythian, K., \& Anisef, P. (2007). The acculturation of Canadian immigrants: Determinants of ethnic identification with the host society. Canadian Review of Sociology/Revue canadienne de sociologie, 44, 37-64. doi:10.1111/j.1755-618X.2007. tb01147.x

Wegge, J., Van Dick, R., Fisher, G. K., Wecking, C., \& Moltzen, K. (2006). Work motivation, organisational identification, and well-being in call centre work. Work \& Stress, 20, 60-83. doi:10.1080/02678370600655553 